\title{
The Effect Of Abnormal Pay Dispersion On Earnings Management
}

\author{
Sanghyuk Byun, Sogang University, South Korea \\ Youngjoo Lee, Sogang University, South Korea \\ Ohjin Kwon, Sogang University, South Korea
}

\begin{abstract}
This study examines the effect of the abnormal pay dispersion on earnings management. Prior studies find that pay dispersion among top executives affect firm performance and executive turnover. We expect that abnormal pay dispersion among top executives affects financial reporting practice as well as firm performance and turnover and provide evidence of positive association between abnormal pay dispersion and earnings management. This result suggests that executives are more likely to be engaged in earnings management to increase their compensation when they feel unfairness from the relative level of compensation. This finding helps financial statement users interpret firm performance and anticipate future outcomes by implying that additional managerial incentives for financial reporting are derived from internal pay dispersion. Our finding that abnormal pay dispersion leads to higher agency costs should also be of interest to shareholders.
\end{abstract}

Keywords: Abnormal Pay Dispersion; Earnings Management; Top Executive Compensation

\section{INTRODUCTION}

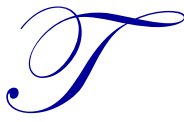

here exist anecdotal examples to illustrate the importance of pay dispersion. J.P. Morgan is reputed, for example, to have been unwilling to invest in a company whose CEO was paid more than 50 percent above the executive at the next level (Rajgopal and Srinivasan, 2006). Further, Ed Woolard, former CEO and Chair of Dupont and current Chair of the NYSE's compensation committee, planned to impose a limit on CEO pay at 1.5 times the pay rate for the executive vice president (Rajgopal and Srinivasan, 2006). Peter Drucker also stated that "one characteristic of poorly performing organization is that top executives are paid more than 130 percent of the compensation of people at the next echelon" (Rajgopal and Srinivasan, 2006).

Several researchers have also shown that executive pay dispersion have influences on managerial decision makings. ${ }^{1}$ However, one of the issues with prior studies is that the behavioral consequences of dispersion examined in the literature are fairly narrow, primarily encompassing firm performance and executive turnover. We expect pay dispersion to influence financial reporting practice in addition to firm performance and executive turnover. The degree of satisfaction with the relative level of compensation affects managerial behavior. When executives derive disutility from the relative level of compensation, they may engage in opportunistic behavior to increase their compensation. ${ }^{2}$ For example, if their compensation depends on financial firm performance, managers could increase compensation via discretion in financial reporting. In this study, we investigate the impact of abnormal pay dispersion on earnings management, since deviation from normal levels of dispersion may provide executives with incentive for opportunistic behavior.

We find that abnormal pay dispersion is positively associated with earnings management. This indicates that executives are more likely to be engaged in earnings management when pay dispersion is deviated from normal level of pay dispersion. The empirical results of this study provide valuable information to investors, regulators and

\footnotetext{
${ }^{1}$ See section 2 for more detailed review.

${ }^{2}$ Prospect theory, which was developed by Kahneman and Tversky (1979), suggests that the value function is not symmetric between losses and gains from the reference point. Instead, it says that slope is steeper for losses than for gains. This means that people have more disutility than utility from same amount of losses versus gains. When an executive regards his total compensation relative to his expectation as a loss, the executive is more likely to reduce his disutility with opportunistic behavior.
} 
auditors. Understanding managerial incentives for financial reporting derived from internal pay dispersion helps financial statement users interpret firm performance and anticipate future outcomes. A finding that abnormal pay dispersion leads to higher agency costs should also be of interest to shareholders. In addition, setting up normal dispersion level that motivates competition among executives with a minimized adverse effect can mitigate potential agency costs.

This study contributes to the accounting literature in several aspects. First, this paper broadens the compensation literature by exploring the effect of pay dispersion on financial reporting practice as well as firm performance and executive turnover. Second, our results suggest that, in addition to compensation structure, internal compensation dispersion is a factor to be considered in structuring executive compensation. Finally, we provide evidence that pay dispersion affects both the level of accounting earnings and mechanisms used to reach those numbers.

The remainder of this paper is organized as follows. Section 2 reviews the related literature and develops hypotheses. Section 3 describes the sample and discusses the research design. Section 4 provides our empirical results and robustness tests. Section 5 concludes the study.

\section{LITERATURE REVIEW AND HYPOHTESES DEVELOPEMENT}

\subsection{Pay Dispersion and Corporate Performance}

Two theories explain the effect of compensation dispersion on managerial behavior. First, tournament theory regards the advancement of executives in the firm hierarchy as a tournament in which they compete for promotion and higher compensation (Lee et al., 2008). According to this theory, an executive with high performance obtains promotion and receives prize, which is higher compensation. This motivates low-level executives to win the competition and exert more efforts (Byun, 2014). Thus, large pay dispersion among corporate hierarchies (i.e., higher compensation at the top level) provides managers with strong incentives to win the tournament and leads to higher efforts (Lazear and Rosen, 1981; Lee et al., 2008).

While arguments for equity fairness theory suggest that high pay dispersion increases envy and dysfunctional behavior among employees and encourages rent-seeking activities (Milgrom and Roberts, 1988; Levine, 1991; Lee et al., 2008). Cowherd and Levien (1992) and Duetsch (1985) argue that cooperation and cohesiveness among the members decrease when lower level workers recognize that they receive less than they deserve. In other words, low pay dispersion reduces conflicts and improves cohesiveness between organization members (Milgrom and Roberts, 1988; Levine, 1991).

Based on the two theories, various empirical studies have investigated how pay dispersion affects firm performance and show mixed empirical results. Main et al. (1993) report a positive relation between pay dispersion among top executive team members and corporate performance. Lee et al. (2008) also examine the effect of compensation dispersion on firm performance. They find that corporate performance is positively associated with the compensation dispersion. These results are consistent with tournament theory.

However, Cowherd and Levine (1992) find that small pay differential between lower-level employees and upperechelon managers leads to high business-unit product quality. Employing a large sample of university and college faculty, Pfeffer and Langton (1993) report that wage inequality within academic departments has a negative impact on faculty members' satisfaction, research productivity, and research collaboration. Bloom (1999) also finds that pay dispersion is negatively associated with individual and organizational performance. These findings are consistent with pay equity theory that large pay dispersion decreases firm performance.

Differently from prior literatures, Byun (2014) assumes that tournament theory and pay equity theory are not mutually exclusive. In addition, he suggests that there is an equilibrium level of pay dispersion, which trades off the motivation to perform (tournament theory) against induced conflict (pay equity theory). Based on this assumption, 
he shows that deviation from the normal level of pay dispersion (hereafter abnormal pay dispersion) is negatively associated with corporate performance. ${ }^{3}$

\subsection{Pay Dispersion and Executive Turnover}

Prior studies regarding pay dispersion examine the effect of pay dispersion on executive turnover. Bloom and Michel (2002) show that pay dispersion within an organization decreases the tenure of managers and increases the likelihood of leaving their organization. Messersmith et al. (2011) also find that pay dispersion is positively associated with the likelihood of executive turnover. While these two studies reveal that executive turnover increases when overall pay dispersion is high, Pfeffer and Davis-Blake (1992) investigate the joint effect of pay dispersion in an organization and individual's location in that distribution on turnover using a sample of administrators in college and university. They find that pay dispersion negatively affects the turnover of administrators with relatively high pay, but it positively related to the turnover of administrators with relatively low pay.

Byun (2014) examines the relation between abnormal pay dispersion among top 5 executives and their turnover. He finds that abnormal pay dispersion is positively associated with executive turnover, which is driven by the result that low-ranked executives (ranked by total compensation) are more likely to leave the firm relative to high-ranked executives (ranked by total compensation) when abnormal pay dispersion is higher than the normal level. Taken together, these results are consistent with the notion that executive turnover is positively associated with disappointment about their compensation.

\subsection{Abnormal Pay Dispersion and Earnings Management}

When abnormal pay dispersion is high (low), low-ranked (highly-ranked) executives may seek a means to shift the pay distribution in their favor. In both cases, executives likely feel that they are underpaid and that the only way to close the gap between what they are earning versus what they believe they should earn is to act opportunistically. One form of opportunistic behavior available to managers with performance-based pay is to manipulate reported earnings. When a firm reports upwardly-biased earnings, executives have a higher probability to receive bonus compensation and the value of their stock holdings increases. ${ }^{4}$ Healy (1985) suggests that bonus schemes provide incentives to manage earnings upward when earnings are between upper and lower boundaries of the bonus plans and incentives to manage earnings downward when earnings are over the upper limit or under the lower limit of the bonus plan.

In addition to executive bonus plans, managers have incentives to meet-or-beat earnings benchmarks (MBE, hereafter) and smooth earnings via earnings management. Prior studies show that executives have compensationrelated incentives to MBE. Matsunaga and Park (2001) find that missing quarterly analyst earnings forecasts reduces CEO annual bonus compensation. Mergenthaler et al. (2011) find that when a firm misses quarterly analyst forecasts, CEO and CFO equity grants and cash bonuses also decrease. Therefore executives who want to increase their total compensation are more likely to be engaged in upward earnings management for attaining bonus target or MBE.

On the other hand, reporting smooth earnings provides incentives to manage earnings downward since firms with low earnings volatility are benefited by higher market value (Trueman and Titman, 1988). Hence executives who want to maximize value of their stock holdings or equity compensation have incentives to manage earnings downward when their firm achieves much higher earnings than previous period. Leone and Rock (2001) also provide evidence of management incentives for income-decreasing accruals management. Following the above

\footnotetext{
${ }^{3}$ Byun (2014) suggests that low (high)-ranked executives are more likely to be dissatisfied with their pay level when pay dispersion is abnormally high (low). Because their relative compensation is lower than what they expect it to be. In all case, dissatisfied executives will not work hard and they are going to leave their company.

${ }^{4}$ If weights on firm performance for compensation purpose differ among the top executives, earnings management may mechanically create dispersion in pay. However, we do not have information about weights for firm performance for each executive. To address this simultaneity issue, we also use a one year ahead value for earnings management as a robustness check.
} 
relation between earnings management and executive compensation, we suggest that abnormal pay dispersion is positively associated with earnings management. We state our hypothesis below.

Hypothesis: Absolute abnormal pay dispersion is positively associated with earnings management.

\section{DATA AND RESEARCH DESIGN}

\subsection{Data}

In this study, we examine the association between abnormal pay dispersion and earnings management. For our analysis, we collect all executive specific information from ExecuComp dataset, which contains not merely compensation information but also executive title, tenure, and whether an executive is a member of board, etc. In addition, we extract financial statement data for firms from Compustat and stock return information from CRSP. Finally, data for corporate governance-related variables are obtained from the Risk Metrics dataset. The sample period runs from 1996 to 2009 because Risk Metrics coverage starts in 1996.

We drop financial firms and utility firms (SIC codes 4400 - 4999 and 6000 - 6499) from our sample for two reasons; i) concern that government regulation may cause different pay structures for these firms, leading to differences in pay dispersion. ii) these firms have different incentives for earnings management and MBE. So inclusion of these firms is likely to add noise in testing our hypotheses, especially for the relation between abnormal pay dispersion and earnings management. Our sample is limited to US companies because there may be a difference between US firms and foreign firms in compensation structures. Consistent with Byun (2014), we restrict our sample to firm-year observations with at least five executives and use the top 5 executives in our test. ${ }^{5}$ Hamm et al. (2011) report that some CEOs receive one dollar salary for several reasons. ${ }^{6}$ We exclude these firms because they may cause noise in the estimation of expected level of pay dispersion ${ }^{7}$ After, we apply these criteria and delete observations that do not contain all data items, we obtain a final sample of 9,105 firm-year observations to estimate normal pay dispersion level.

\subsection{Estimation of Normal Pay Dispersion Level}

Following Byun (2014), we estimate the normal pay dispersion level for each firm-year observation using the regression model (1).

$$
\begin{aligned}
& \text { PD }_{\mathrm{t}}= \alpha+\beta_{1} * \text { St_Tenure } \\
& \mathrm{t}
\end{aligned}
$$

Where:

$\mathrm{PD}=$ Pay dispersion. The coefficient of variation $(\mathrm{CV})$ of total compensation for top 5executives

St_Tenure $=\mathrm{CV}$ of tenures for top 5 executives

St_Exp $=$ CV of previous experience dummy for top 5 executives; previous experience dummy is 1

if an executive has previous work experience at other S\&P 1500 firms as a top executive

\footnotetext{
${ }^{5}$ Byun (2014) argues that variation in the number of executives may mechanically affect pay dispersion in cases with more than five executives reported. Thus, we also use only top 5 highly paid executives in our test when a firm-year observation includes more than five executives in ExecuComp dataset.

${ }^{6}$ For example, Steve Jobs, a former CEO of Apple Inc., received only a single dollar salary for his total compensation although his internal power is enormous.

${ }^{7}$ We also exclude firms whose CEOs receive less than $\$ 1,000$ for total compensation.
} 


$$
\begin{aligned}
& \text { St_ROA }=\text { CV of industry mean-adjusted career ROA for top } 5 \text { executives } \\
& \text { St_Ret }=\text { CV of industry mean-adjusted career stock return for top } 5 \text { executives } \\
& \text { St_HResp = CV of dummies for executives who holds chairman, CEO, CFO and/or COO } \\
& \text { St_Board = CV of dummies for executives on the board among top } 5 \text { executives } \\
& \text { St_Hold = CV of stock holdings for top } 5 \text { executives } \\
& \text { Dual = } 1 \text { if the CEO has a chairman title; } 0 \text {, otherwise } \\
& \text { Size = Natural logarithm of total assets } \\
& \text { Seg = Number of business segments } \\
& \text { Ch_Sale = Sales change from year t- } 1 \text { to year } t \text { scaled by Sales in year t-1 } \\
& \text { MTB = Market-to-book ratio } \\
& \text { BSize = Number of directors on the board } \\
& \text { BIndep = Proportion of independent directors on the board } \\
& \text { BlockHolder = Number of independent directors who own greater than } 5 \text { percent of the equity of the firm } \\
& \text { Fe_Ratio = Proportion of female executives among top five executives }
\end{aligned}
$$

Our measure of pay dispersion (PD), which is dependent variable in equation (1), is the coefficient of variation (hereafter $\mathrm{CV}$ ) of total compensation for top 5 executives. We calculate $\mathrm{CV}$ of total compensation as standard deviation of total compensation divided by mean total compensation for the top five executives. ${ }^{8}$ Three types of variation in executive characteristics are included in our regression model because we expect that executive characteristics are likely to contribute to variation of pay dispersion between firms (Byun, 2014):

(1) Executive ability; Companies are more likely to set a different pay amount for each executive when variation in executive ability within a company is high. Thus, we expect pay dispersion to be high when the variation in CEO's ability is high. We adopt industry mean-adjusted accounting performance (St_ROA) and stock price performance (St_Ret) as a proxy for executive ability. Following prior studies, we also include tenures (St_Tenure) and previous work experience of executive (St_Exp) as a proxy for executive ability (Milbourn, 2003; Rajgopa et al., 2006; Byun, 2014).

(2) Executive responsibility; Agarwal (1981) shows that variation in responsibility leads to variation in pay. Most executives in the top 5 ranks are greatly responsible for firm performance but some executives who are chairman, CEO, CFO, and/or COO have more responsibility than others (St_HResp). Board members are also more responsible for firm performance (St_Board). We expect that the variation in responsibility decreases when firm has more responsible executives in its top 5 ranks.

\footnotetext{
${ }^{8}$ Byun (2014) picks CV as a measure of variation for two reasons. First, executive total compensation is positively associated with firm size. Because $\mathrm{CV}$ is a dispersion measure that can be interpreted in the context of the mean of total compensation, it allows comparison among dispersion levels for firms with different sizes. Second, using CV makes his findings comparable to prior studies' findings (Rajgopal and Srinivasan, 2006; Lee et al., 2008).
} 
(3) Executive power; Prior studies report that ownership power is most likely related to pay dispersion. Executives with higher ownership generally hold more power because of higher capacity as an agent on behalf of shareholders (Finkelstein, 1992). Thus we include ownership which is measured by executive stock holding in the regression model (St_Hold). We also consider dual position power (Dual) as a CEO and a chairman because both CEO and chairman occupy the most main position in the company and they have higher influence in controlling compensation relative to other executives (Byun, 2014).

In addition to three types of characteristics explained above, we include firm characteristics such as firm size, number of segments, and market to book ratio in the regression model following previous studies (Lee at al., 2008; Core et al., 1999; Ashbaugh et al., 2006; Byun et al., 2014). Finally, we contain year dummies and industry dummies in equation (1) to control for industry and year fixed effects. Fitted values from estimating equation (1) provide normal pay dispersion and residuals are abnormal pay dispersion, which is deviation from expected level of pay dispersion. Abnormal pay dispersion will be the variable of interest in subsequent analyses.

\subsection{Earnings Management}

To test the effect of abnormal pay dispersion on manager's decision making about earnings management, we employ accruals management and real earnings management. Following subsections explain measures of earnings management and models to test our hypothesis.

\subsubsection{Accruals Management}

We adopt the modified Jones model from Dechow, Sloan and Sweeny (1995), controlling for contemporaneous ROA as suggested by Kothari, Leone, and Wasley (2005), to calculate discretionary accruals as our measure of earnings management. We calculate total accruals following Hribar and Collins (2002) using the cash flow statement approach. The first stage model to estimate expected accruals level is as below.

$$
\mathrm{TA}_{\mathrm{t}} / \mathrm{A}_{\mathrm{t}-1}=\alpha *\left[1 / \mathrm{A}_{\mathrm{t}-1}\right]+\beta_{1} *\left[\Delta \mathrm{REV}_{\mathrm{t}} / \mathrm{A}_{\mathrm{t}-1}\right]+\beta_{2} *\left[\mathrm{PPE}_{\mathrm{t}} / \mathrm{A}_{\mathrm{t}-1}\right]+\beta_{3} * \mathrm{ROA}_{\mathrm{t}}+\mathrm{e}_{\mathrm{t}}
$$

Where:

$\mathrm{TA}=$ Total accruals defined as income before extraordinary items minus cash flow from operations

$$
\begin{aligned}
& \mathrm{A}=\text { Total assets } \\
& \triangle \mathrm{REV}=\text { Change in revenue from prior year } \\
& \mathrm{PPE}=\text { Gross property, plant and equipment }
\end{aligned}
$$

We run the above cross-sectional regression for each year by industry as defined by two-digit SIC code. We exclude industry-years that contain fewer than 10 observations. We take the coefficient estimates from equation (2) and obtain the fitted values for each firm-year to obtain the expected accruals as shown in the equation below.

$$
\mathrm{NDA}=\hat{\alpha} *\left[1 / \mathrm{A}_{\mathrm{t}-1}\right]+\hat{\beta}_{1} *\left[\left(\Delta \mathrm{REV}_{\mathrm{t}}-\Delta \mathrm{AR}\right) / \mathrm{A}_{\mathrm{t}-1}\right]+\hat{\beta}_{2} *\left[\mathrm{PPE}_{\mathrm{t}} / \mathrm{A}_{\mathrm{t}-1}\right]+\hat{\beta}_{3} * \mathrm{ROA}_{\mathrm{t}}+\mathrm{e}_{\mathrm{t}}
$$

Where:

$$
\begin{aligned}
& \mathrm{NDA}=\text { Non-discretionary accruals } \\
& \Delta \mathrm{AR}=\text { Change in accounts receivable from prior year }
\end{aligned}
$$


We subtract the estimated expected accruals from the firm's actual total accruals to find the discretionary accruals by firm. Positive (negative) discretionary accruals indicate upward (downward) earnings management. We use absolute value of discretionary accruals as a measure of accruals management because we expect abnormal pay dispersion provides incentives for both upward and downward earnings management. We estimate the following regression with potential factors that are likely to affect the decision to engage in earnings management to investigate the association between pay dispersion and accruals management

$$
\begin{aligned}
& \mathrm{Ab} \_\mathrm{DA} A_{\mathrm{t}}=\alpha+\beta_{1} * \mathrm{Ab} \_\mathrm{APD}_{\mathrm{t}}+\beta_{2} * \mathrm{NPD}_{\mathrm{t}}+\beta_{3} * \mathrm{Size}_{\mathrm{t}}+\beta_{4} * \mathrm{MTB}_{\mathrm{t}}+\beta_{5} * \mathrm{Lev}_{\mathrm{t}}+\beta_{6} * \text { CEO_Equity_Ratio } \\
& +\beta_{7} * \mathrm{NOA}_{\mathrm{t}}+\beta_{8} * \text { Litigation }_{\mathrm{t}}+\beta_{9} * \text { Implicit_Claim }_{\mathrm{t}}+\beta_{10} * \mathrm{SOX}_{\mathrm{t}}+\mathrm{e}_{\mathrm{t}}
\end{aligned}
$$

Where:

Ab_DA $=$ Absoulte value of discretionary accruals calculated from modified Jones model

Ab_APD $=$ Absolute value of abnormal pay dispersion defined as residual from estimating equation (1)

NPD $=$ Normal pay dispersion

Size $=$ Natural logarithm of total assets

MTB $=$ Market-to-book ratio

Lev $=$ Leverage computed as total liability divided by total assets

CEO_Equity_Ratio $=$ CEO equity compensation scaled by CEO total compensation

NOA $=$ Net operating assets calculated as (shareholders' equity minus cash and marketable securities plus total debt) / sales

Litigation $=1$ if the firm is in one of the following SIC codes: 2833-2836, 8731-8734, 3570-3577, 7370-7374, 3600-3674, 5200-5961; 0, otherwise

Implicit_Claim $=1$ minus the ratio of gross PPE to total assets

$\mathrm{SOX}=1$ if the year is after $2003 ; 0$ otherwise

The main coefficient of interest in equation (4) is $\beta_{1}$. When deviation from normal level of dispersion provides incentives to manage earnings regardless of direction, $\beta_{1}$ is expected to be positive. If one theory (tournament vs. pay equity) dominates, $\beta_{1}$ is expected to be insignificant. Barton and Simko (2002) show that firms with already overstated assets have a lack of flexibility of managing earnings upward using accruals. We, therefore, include NOA in the regression but do not have a directional expectation. The coefficient on Litigation is expected to be positive because firms with high litigation risk may want to reduce potential litigation risk caused by upward earnings management. Implicit_Claim is expected to be negatively associated with DA because firms with high implicit claims are likely to choose long-run income-increasing accounting methods (Bowen et al. 1995), so we expect a positive coefficient. Following prior studies, we expect negative coefficients of SOX, but the coefficient can be positive if the magnitude of downward earnings management in which firms are engaged became larger after SOX. We also include CEO_Equity_Ratio to control for CEO individual incentives for earnings management.

\subsubsection{Real Earnings Management}

In addition to discretionary accruals, we also test our hypothesis adopting two real earnings management measures from Roychowdhury (2006) and Gunny (2010) as further proxies for earnings management. We explain the measurement of two measures below. 


\subsection{Abnormal Expenses (R\&D and SG\&A Expense)}

After we estimate the following models to obtain normal level of R\&D expense and SG\&A expense respectively, we subtract the expected expenses from actual expenses. These become our measures of abnormal R\&D expense and abnormal SG\&A expense. As our first measure for real earnings management, similar to our measure of discretionary accruals, we add these two abnormal expenses and take an absolute value. Therefore a higher absolute value of abnormal expense indicates a higher level of earnings management. We run the following regression for all firms in a given industry by year.

$$
\begin{aligned}
& \mathrm{RD}_{\mathrm{t}} / \mathrm{A}_{\mathrm{t}-1}=\alpha_{0}+\alpha_{1} *\left[1 / \mathrm{A}_{\mathrm{t}-1}\right]+\beta_{1} * \mathrm{MV}_{\mathrm{t}}+\beta_{2} * \mathrm{Q}_{\mathrm{t}}+\beta_{3} *\left[\mathrm{INT}_{\mathrm{t}-1} / \mathrm{A}_{\mathrm{t}-1}\right]+\beta_{4} *\left[\mathrm{RD}_{\mathrm{t}-1} / \mathrm{A}_{\mathrm{t}-1}\right]+\mathrm{e}_{\mathrm{t}} \\
& \mathrm{SGA}_{\mathrm{t}} / \mathrm{A}_{\mathrm{t}-1}=\alpha_{0}+\alpha_{1} *\left[1 / \mathrm{A}_{\mathrm{t}-1}\right]+\beta_{1} * \mathrm{MV}_{\mathrm{t}}+\beta_{2} * \mathrm{Q}_{\mathrm{t}}+\beta_{3} *\left[\mathrm{INT}_{\mathrm{t}-1} / \mathrm{A}_{\mathrm{t}-1}\right]+\beta_{4} *\left[\Delta \mathrm{S}_{\mathrm{t}-1} / \mathrm{A}_{\mathrm{t}-1}\right] \\
& +\beta_{5} *\left[\Delta \mathrm{S}_{\mathrm{t}-1} / \mathrm{A}_{\mathrm{t}-1}\right] * \mathrm{DD}+\mathrm{e}_{\mathrm{t}}
\end{aligned}
$$

Where:

$$
\begin{aligned}
& \mathrm{RD}=\mathrm{R} \& \mathrm{D} \text { Expense } \\
& \mathrm{SGA}=\mathrm{SG} \& \mathrm{~A} \text { expense } \\
& \mathrm{MV}=\text { The natural log of market value } \\
& \mathrm{Q}=\text { Tobin's } \mathrm{Q} \text { calculated as [market value of equity + preferred stock carrying value }+ \text { long-term debt } \\
& + \text { debt in current liabilities] / total assets } \\
& \text { INT }=\text { Internal funds calculated as (income before extraordinary item }+ \text { R\&D expense }+ \text { depreciation and } \\
& \text { amortization) } \\
& \Delta \mathrm{S}=\text { Change of total sales }
\end{aligned}
$$

\subsection{Abnormal Production Level}

Similar to our estimation of normal R\&D expense and normal SG\&A expense, we estimate the normal level of production and then subtract the normal level from the actual level. The difference between the normal level and the actual level of production is the abnormal production level. A higher absolute value of abnormal production indicates a higher level of earnings management.

$$
\operatorname{PROD}_{\mathrm{t}} / \mathrm{A}_{\mathrm{t}-1}=\alpha_{0}+\alpha_{1} *\left[1 / \mathrm{A}_{\mathrm{t}-1}\right]+\beta_{1} * \mathrm{MV}_{\mathrm{t}}+\beta_{2} * \mathrm{Q}_{\mathrm{t}}+\beta_{3} *\left[\mathrm{~S}_{\mathrm{t}} / \mathrm{A}_{\mathrm{t}-1}\right]+\beta_{4} *\left[\Delta \mathrm{S}_{\mathrm{t}} / \mathrm{A}_{\mathrm{t}-1}\right]+\beta_{5} *\left[\Delta \mathrm{S}_{\mathrm{t}-1} / \mathrm{A}_{\mathrm{t}-1}\right]+\mathrm{e}_{\mathrm{t}}
$$

Where:

$$
\begin{aligned}
& \text { PROD = COGS plus change in inventory } \\
& \mathrm{S}=\text { Total sales }
\end{aligned}
$$

We run the following regression to test the hypothesis, which examines the relation between abnormal pay dispersion and earnings management. Except for coefficients of NOA and SOX, our expectations about the directions of all coefficients are same as for equation (4). If firms want to manage earnings upward when they are no longer able to manipulate accruals, they may convert to real activity management. Therefore we do not have a directional prediction on NOA. ${ }^{9}$ We expect a positive relation between real earnings management and SOX since

\footnotetext{
${ }^{9}$ Both Cohen et al. (2008) and Cohen and Zarowin (2010) find positive association between SOX and REM.
} 
prior studies show such an association. In testing our hypothesis, we expect a positive coefficient of $\beta_{1}$ for both absolute value of abnormal expense and abnormal production.

$$
\begin{aligned}
& \text { Ab_REM }{ }_{\mathrm{t}}=\alpha+\beta_{1} * \text { Abs_APD }{ }_{\mathrm{t}}+\beta_{2} * \mathrm{NPD}_{\mathrm{t}}+\beta_{3} * \mathrm{Size}_{\mathrm{t}}+\beta_{4} * \mathrm{MTB}_{\mathrm{t}}+\beta_{5} * \mathrm{Lev}_{\mathrm{t}}+\beta_{6} * \text { CEO_Equity_Ratio } \\
& +\beta_{7} * \mathrm{NOA}_{\mathrm{t}}+\beta_{8} * \text { Litigation }_{\mathrm{t}}+\beta_{9} * \text { Implicit_Claim }_{\mathrm{t}}+\beta_{10} * \mathrm{SOX}_{\mathrm{t}}+\mathrm{e}_{\mathrm{t}}
\end{aligned}
$$

Where:

$\mathrm{Ab} \_\mathrm{REM}=$ Absolute value of each real earnings management measure

\section{EMPIRICAL RESULTS}

\subsection{Descriptive Statistics}

Table 1 describes distribution of abnormal pay dispersion (APD) and absolute value of abnormal pay dispersion (Ab_APD) and descriptive statistics for other variables used in this study. By construction, the mean of APD is zero. More importantly, APD and AB_APD show considerable variation within the sample. Untabulated result indicates that about $55.6 \%$ of sample firm-years have lower pay dispersion than expected. The mean and median of discretionary accruals (Ab_DA) are 0.056 and 0.041 respectively. The average Ab_PREM (Ab_EREM) as a proxy for real earnings management is $0.233(0.237)$. The average of MTB ratio is 3.968 . On average, $\overline{\mathrm{C}}$ EO receives equity compensation that is $43 \%$ of total compensation in our sample.

Table 1. Description of Abnormal Pay Dispersion and Main Variables

\begin{tabular}{l|c|c|c|c|c}
\hline & Mean & Median & Std & Q1 & Q3 \\
\hline APD & -0.000 & -0.030 & 0.254 & -0.165 & 0.122 \\
\hline Ab_APD & 0.191 & 0.148 & 0.167 & 0.068 & 0.265 \\
\hline Ab_DA & 0.056 & 0.041 & 0.053 & 0.019 & 0.077 \\
\hline Ab_PREM & 0.233 & 0.149 & 0.281 & 0.065 & 0.283 \\
\hline Ab_EREM & 0.237 & 0.141 & 0.329 & 0.058 & 0.281 \\
\hline Size & 7.410 & 7.286 & 1.415 & 6.416 & 8.287 \\
\hline MTB & 3.968 & 2.377 & 3.163 & 1.582 & 3.829 \\
\hline Lev & 0.217 & 0.211 & 0.171 & 0.071 & 0.324 \\
\hline CEO_Equity_Ratio & 0.431 & 0.459 & 0.281 & 0.217 & 0.651 \\
\hline NOA & 0.663 & 0.532 & 0.713 & 0.344 & 0.784 \\
\hline Litigation & 0.346 & 0 & 0.476 & 0 & 1 \\
\hline SOXplicit_Claim & 0.448 & 0.533 & 0.366 & 0.247 & 0.729 \\
\hline APD is & 0.477 & 0 & 0.499 & 0 & 1 \\
\hline
\end{tabular}

$\boldsymbol{A P D}$ is residual from equation (1). $\boldsymbol{A} \boldsymbol{A} \_\boldsymbol{A P D}$ is absolute value of APD. $\boldsymbol{A} \boldsymbol{b} \_\boldsymbol{D} \boldsymbol{A}$ is absolute value of discretionary accruals calculated from modified Jones model. A A _ PREM is absolute value of abnormal production calculated from Roychowdhury (2006) and Gunny (2010). Ab_EREM is absolute value of sum of abnormal R\&D expense and abnormal SG\&A expense calculated from Roychowdhury (2006) and Gunny (2010). Size is natural logarithm of total assets. MTB is market-to-book ratio. $\boldsymbol{L} \boldsymbol{e v}$ is leverage computed as total liability divided by total assets. CEO_Equity_Ratio is CEO equity compensation scaled by CEO total compensation. NOA is net operating assets calculated as (shareholders' equity minus cash and marketable securities plus total debt) / sales. Litigation is 1 if the firm is in one of the following SIC codes: 2833-2836, 8731-8734, 3570-3577, 7370-7374, 3600-3674, 5200-5961; 0, otherwise. Implicit_Claim is proxied by labor intensity calculated as 1 minus the ratio of gross PPE to total assets. SOX is 1 if the year is after 2003; 0 otherwise.

\subsection{Testing Hypotheses}

Table 2 and 3 present the results of testing the association between abnormal pay dispersion and earnings management. Table 2 reports the results for discretionary accruals. The coefficient on Ab_APD is positive and significant as expected. This provides support for our hypothesis that abnormal pay dispersion is positively associated with earnings management. ${ }^{10}$ Change in Ab_APD from the first quartile to the third quartile increases discretionary accruals by $0.12 \%$ of total assets. This increase is about $2 \%$ of the sample mean discretionary accruals

\footnotetext{
${ }^{10}$ We include raw pay dispersion in the equation (4) to check whether our result still holds even after controlling raw pay dispersion. Untabulated result shows positive coefficient on Ab_APD and negative coefficient on raw pay dispersion, which confirms that our result is robust.
} 
of 5.6\%. Most control variables show the expected signs. Table 3 provides the estimation results of regression (8) for real earnings management. The coefficients on Ab_APD are significantly positive for both real earnings management measures, consistent with accruals management. Coefficients on most control variables show the expected directions as indicated previously.

Table 2. Effect of Abnormal Pay dispersion on Accruals Management

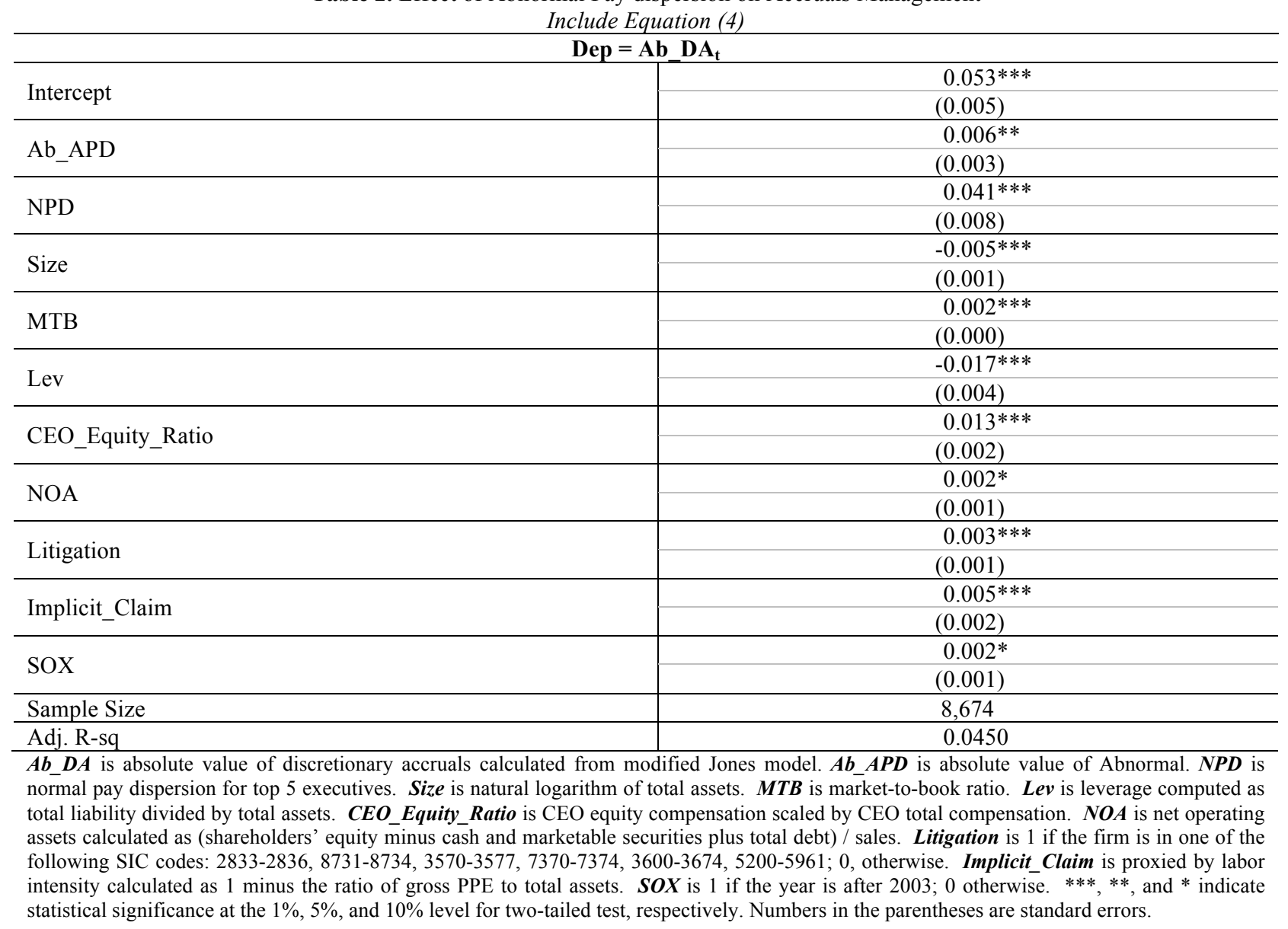

Overall, results for accruals management are consistent with our expectations. To confirm the relation between abnormal pay dispersion and earnings management, we test the effect of abnormal pay dispersion on directional earnings management in subsamples where firms are considered to be more likely engaged in upward earnings management (untabulated). For example, we re-estimate equation (4) by replacing dependent variables with directional earnings management measures in subsamples where firms meet or just beat analyst forecasts, prior year's earnings, or zero earnings. However, the results do not support the expectation that abnormal pay dispersion increases upward earnings management. Therefore, we leave the relation between abnormal pay dispersion and directional earnings management as a future research question. 
Table 3. Effect of Abnormal Pay dispersion on Real Earnings Management

\begin{tabular}{|c|c|c|}
\hline & Dep = Ab_PREM & Dep $=$ Ab_EREM \\
\hline \multirow{2}{*}{ Intercept } & $0.219 * * *$ & 0.025 \\
\hline & $(0.028)$ & $(0.043)$ \\
\hline \multirow{2}{*}{$\mathrm{Ab} \_\mathrm{APD}$} & $0.043 * *$ & $0.082 * *$ \\
\hline & $(0.020)$ & $(0.032)$ \\
\hline \multirow{2}{*}{ NPD } & $-0.082 *$ & 0.021 \\
\hline & $(0.046)$ & $(0.073)$ \\
\hline \multirow{2}{*}{ Size } & -0.002 & $0.013 * * *$ \\
\hline & $(0.003)$ & $(0.004)$ \\
\hline \multirow{2}{*}{ MTB } & $0.005 * * *$ & $0.007 * * *$ \\
\hline & $(0.001)$ & $(0.002)$ \\
\hline \multirow{2}{*}{ Lev } & 0.013 & $-0.104 * * *$ \\
\hline & $(0.023)$ & $(0.030)$ \\
\hline \multirow{2}{*}{ CEO_Equity_Ratio } & 0.000 & -0.018 \\
\hline & $(0.012)$ & $(0.020)$ \\
\hline \multirow{2}{*}{ NOA } & $-0.048 * * *$ & $0.034 * *$ \\
\hline & $(0.007)$ & $(0.014)$ \\
\hline \multirow{2}{*}{ Litigation } & $0.020 * * *$ & $0.056^{* * *}$ \\
\hline & $(0.007)$ & $(0.009)$ \\
\hline \multirow{2}{*}{ Implicit_Claims } & $0.125 * * *$ & $0.120 * * *$ \\
\hline & $(0.009)$ & $(0.015)$ \\
\hline \multirow{2}{*}{ SOX } & $0.038 * * *$ & $-0.026^{* * *}$ \\
\hline & $(0.006)$ & $(0.008)$ \\
\hline Sample Size & 7,920 & 5,260 \\
\hline Adj. R-sq & 0.047 & 0.041 \\
\hline
\end{tabular}

$\boldsymbol{A} \boldsymbol{A} \_$PREM is absolute value of abnormal production calculated from Roychowdhury (2006) and Gunny (2010). $\boldsymbol{A} \boldsymbol{B} \_$EREM is absolute value of sum of abnormal R\&D expense and abnormal SG\&A expense calculated from Roychowdhury (2006) and Gunny (2010). $\boldsymbol{A} \boldsymbol{b} \_\boldsymbol{A P D}$ is absolute value of APD. Size is natural logarithm of total assets. NPD is normal pay dispersion for top 5 executives. $M$ MTB is market-to-book ratio. $\mathbf{L} \boldsymbol{e v}$ is leverage computed as total liability divided by total assets. CEO_Equity_Ratio is CEO equity compensation scaled by CEO total compensation. $\boldsymbol{N O A}$ is net operating assets calculated as (shareholders' equity minus cash and marketable securities plus total debt) / sales. Litigation is 1 if the firm is in one of the following SIC codes: 2833-2836, 8731-8734, 3570-3577, 7370-7374, 3600-3674, 5200-5961; 0, otherwise. Implicit Claim is proxied by labor intensity calculated as 1 minus the ratio of gross PPE to total assets. SOX is 1 if the year is after $2003 ; 0$ otherwise. ***,**, and $*$ indicate statistical significance at the $1 \%, 5 \%$, and $10 \%$ level for two-tailed test, respectively. Numbers in the parentheses are standard errors.

\subsection{Robustness Check}

To relieve a concern that the results about earnings management are affected by reverse causality, we include only salary in estimating abnormal pay dispersion. Since executives are presumed to know their relative salary level at the beginning of the period, examining relation between abnormal salary dispersion and contemporaneous earnings management is free from issue about reverse causal direction. Hence we revisit our hypotheses by using only salary in determinants model. Table 4 provides results for abnormal salary dispersion effect on earnings management. By using only salary in estimating abnormal pay dispersion, the relation between abnormal salary dispersion and earnings management confirms the main results. As another robustness check for simultaneity issue, we also use a one year ahead value for earnings management as a robustness check. Untabulated results show qualitatively similar results. 
Table 4. Robustness check with using only salary instead of total compensation

\begin{tabular}{|c|c|c|c|}
\hline & \multicolumn{2}{|c|}{ Accruals Management } & Real Earnings Management \\
\hline & Dep $=$ Ab_DA $A_{t}$ & Dep $=$ Ab_PREM ${ }_{t}$ & Dep $=$ Ab_EREM $\mathbf{t}_{\mathrm{t}}$ \\
\hline \multirow{2}{*}{ Intercept } & $0.075 * * *$ & $0.398 * * *$ & $0.353 * * *$ \\
\hline & $(0.004)$ & $(0.036)$ & $(0.052)$ \\
\hline \multirow{2}{*}{$\mathrm{Ab} \_\mathrm{APD}$} & $0.011 *$ & 0.029 & 0.030 \\
\hline & $(0.006)$ & $(0.038)$ & $(0.053)$ \\
\hline \multirow{2}{*}{ NPD } & -0.017 & $-0.538 * * *$ & $-0.799 * * *$ \\
\hline & $(0.012)$ & $(0.072)$ & $(0.104)$ \\
\hline \multirow{2}{*}{ Size } & $-0.004 * * *$ & -0.000 & $0.020 * * *$ \\
\hline & $(0.000)$ & $(0.003)$ & $(0.004)$ \\
\hline \multirow{2}{*}{ MTB } & $0.002 * * *$ & $0.004 * * *$ & $0.006 * * *$ \\
\hline & $(0.000)$ & $(0.001)$ & $(0.002)$ \\
\hline \multirow{2}{*}{ Lev } & $-0.016^{* * *}$ & 0.024 & $-0.073 * *$ \\
\hline & $(0.004)$ & $(0.023)$ & $(0.030)$ \\
\hline \multirow{2}{*}{ CEO_Equity_Ratio } & $0.015 * * *$ & 0.000 & -0.019 \\
\hline & $(0.002)$ & $(0.012)$ & $(0.019)$ \\
\hline \multirow{2}{*}{ NOA } & $0.002 *$ & $-0.050 * * *$ & $0.029 * *$ \\
\hline & $(0.001)$ & $(0.007)$ & $(0.014)$ \\
\hline \multirow{2}{*}{ Litigation } & $0.003^{* *}$ & $0.016^{* *}$ & $0.041 * * *$ \\
\hline & $(0.001)$ & $(0.007)$ & $(0.009)$ \\
\hline \multirow{2}{*}{ Implicit_Claim } & $0.006 * * *$ & $0.117 * * *$ & $0.113 * * *$ \\
\hline & $(0.002)$ & $(0.009)$ & $(0.015)$ \\
\hline \multirow{2}{*}{ SOX } & $0.002 *$ & $0.034 * * *$ & $-0.035 * * *$ \\
\hline & $(0.001)$ & $(0.006)$ & $(0.009)$ \\
\hline Sample Size & 8,674 & 7,920 & 5,260 \\
\hline Adj. R-sq & 0.042 & 0.053 & 0.049 \\
\hline
\end{tabular}

$\boldsymbol{A b} \boldsymbol{D} \boldsymbol{A}$ is absolute value of discretionary accruals calculated from modified Jones model. $\boldsymbol{A b} \boldsymbol{P R E \boldsymbol { M }}$ is absolute value of abnormal production calculated from Roychowdhury (2006) and Gunny (2010). $\boldsymbol{A}$ b_EREM is absolute value of sum of abnormal R\&D expense and abnormal SG\&A expense calculated from Roychowdhury (2006) and Gunny (2010). $\boldsymbol{A} \boldsymbol{b} \_\boldsymbol{A P D}$ is absolute value of Abnormal. NPD is normal pay dispersion for top 5 executives. Size is natural logarithm of total assets. $\boldsymbol{M T B}$ is market-to-book ratio. $\mathbf{L e v}$ is leverage computed as total liability divided by total assets. CEO Equity Ratio is CEO equity compensation scaled by CEO total compensation. $\boldsymbol{N O \boldsymbol { A }}$ is net operating assets calculated as (shareholders' equity minus cash and marketable securities plus total debt)/ sales. Litigation is 1 if the firm is in one of the following SIC codes: 2833-2836, 8731-8734, 3570-3577, 7370-7374, 3600-3674, 5200-5961; 0, otherwise. Implicit_Claim is proxied by labor intensity calculated as 1 minus the ratio of gross PPE to total assets. $\boldsymbol{S O X}$ is 1 if the year is after $2003 ; 0$ otherwise. ${ }^{* * *},{ }^{* *}$, and * indicate statistical significance at the $1 \%, 5 \%$, and $10 \%$ level for two-tailed test, respectively. Numbers in the parentheses are standard errors.

As a further sensitivity check, we employ accruals quality measure from the Dechow-Dichev model as modified by Francis et al. (2005) to test abnormal pay dispersion effect on accruals management. The Dechow-Dichev model focuses on the relation between current accruals and past, present, and future cash flows. Furthermore, Francis et al. (2005) include the change in revenue and property, plant, and equipment in the Dechow-Dichev model. The results also confirm the positive association between abnormal pay dispersion and accruals management by showing that the higher absolute value of abnormal pay dispersion leads to the lower earnings quality. 
Table 5. Robustness Check with Using Francis et al. (2005) model.

\begin{tabular}{|c|c|}
\hline & Dep $=$ Ab_DD \\
\hline \multirow{2}{*}{ Intercept } & $0.063 * * *$ \\
\hline & $(0.003)$ \\
\hline \multirow{2}{*}{ Ab_APD } & $0.019 * * *$ \\
\hline & $(0.003)$ \\
\hline \multirow{2}{*}{ NPD } & $-0.006 * * *$ \\
\hline & $(0.002)$ \\
\hline \multirow{2}{*}{ Size } & $-0.005 * * *$ \\
\hline & $(0.001)$ \\
\hline \multirow{2}{*}{ MTB } & $0.001 * * *$ \\
\hline & $(0.000)$ \\
\hline \multirow{2}{*}{ Lev } & $0.009 * *$ \\
\hline & $(0.004)$ \\
\hline \multirow{2}{*}{ CEO_Equity_Ratio } & $0.013 * * *$ \\
\hline & $(0.002)$ \\
\hline \multirow{2}{*}{ NOA } & $0.002 * *$ \\
\hline & $(0.001)$ \\
\hline \multirow{2}{*}{ Litigation } & $0.004 * * *$ \\
\hline & $(0.001)$ \\
\hline \multirow{2}{*}{ Implicit_Claim } & $0.006^{* * *}$ \\
\hline & $(0.002)$ \\
\hline \multirow{2}{*}{ SOX } & 0.001 \\
\hline & $(0.001)$ \\
\hline Sample Size & 8,297 \\
\hline Adj. R-sq & 0.0352 \\
\hline
\end{tabular}

$\boldsymbol{A b} \_\boldsymbol{D D}$ is absolute value of accruals quality calculated from the model in Francis et al. (2005). $\boldsymbol{A b} \_\boldsymbol{A P D}$ is absolute value of Abnormal. $\boldsymbol{N P D}$ is normal pay dispersion for top 5 executives. Size is natural logarithm of total assets. MTB is market-to-book ratio. Lev is leverage computed as total liability divided by total assets. CEO_Equity_Ratio is CEO equity compensation scaled by CEO total compensation. NOA is net operating assets calculated as (shareholders' equity minus cash and marketable securities plus total debt) / sales. Litigation is 1 if the firm is in one of the following SIC codes: 2833-2836, 8731-8734, 3570-3577, 7370-7374, 3600-3674, 5200-5961; 0, otherwise. Implicit_Claim is proxied by labor intensity calculated as 1 minus the ratio of gross PPE to total assets. SOX is 1 if the year is after 2003; 0 otherwise. ***,**, and * indicate statistical significance at the $1 \%, 5 \%$, and $10 \%$ level for two-tailed test, respectively. Numbers in the parentheses are standard errors.

Some firm-year observations in ExecuComp database contain valid information for fewer than five executives. Limiting our sample to firm-years with five executives may lose a lot of observations and affect our results. To avoid this issue, we restrict our sample to firm-years with at least three executives and retest analysis (untabulated). Results are qualitatively similar.

\section{CONCLUSION}

Prior studies document that pay dispersion among top executives affects firm performance and executive turnover based on tournament theory and pay equity theory. We expect that abnormal pay dispersion among top executives affects financial reporting practice as well as firm performance and turnover and provide evidence of positive association between abnormal pay dispersion and earnings management. Findings of this study contribute to the accounting literature by reporting that abnormal pay dispersion may increase agency costs by providing incentives for rent-seeking behavior and shed a light on the importance of setting appropriate relative compensation level among executives. Finally, this study suggests the examination of association between abnormal pay dispersion and directional earnings management as a further step in research about abnormal pay dispersion. It could be interesting to explore in which circumstances abnormal pay dispersion influences upward or downward earnings management.

\section{AUTHOR BIOGRAPHIES}

Sanghyuk Byun, Ph.D., Assistant Professor of Accounting, Sogang Business School, Sogang University, 35 Baekbeom-ro, Mapo-gu, Seoul, Korea. E-mail: sbyun@sogang.ac.kr (First Author) 
Youngjoo Lee, Ph.D., Assistant Professor of Finance, Sogang Business School, Sogang University, 35 Baekbeomro, Mapo-gu, Seoul, Korea. E-mail: yjlee20@sogang.ac.kr (Corresponding Author)

Ohjin, Kwon, Ph.D. candidate and lecturer of Business Administration (BA) has been teaching at Bucheon University since 2014. He has been majoring the BA (Accounting) to achieve doctor degree at Sogang University since 2012. He received the Master of Financial Accounting degree from Sogang University. He also worked at trust company for 5 years. His research focuses on the investment efficiency, CSR, earnings management and corporate governance. Ohjin Kwon, School of Business, Sogang University, 35 Baekbumro, Mapogu, Seoul, 121-742, South Korea. E-mail: arbiter97@hanmail.net

\section{REFERENCES}

Agarwal, N. (1981). Determinants of Executive Compensation. Industrial Relations 20 (1), 36-46.

Ashbaugh, H., D. Collins, and R. Lafond. (2006). The effect of corporate governance on firms' credit ratings. Journal of Accounting and Economics 42, 203-243.

Barton, J., and P. Simko. (2002). The Balance Sheet as an Earnings Management Constraint. The Accounting Review 77, 1-27.

Bloom, M. (1999). The Performance Effects of Pay Dispersion on Individuals and Organizations. The Academy of Management Journal 42 (1), 25-40.

Bloom, M., and J. Michel. (2002). The Relationships among Organizational Context, Pay Dispersion, and Managerial Turnover. The Academy of Management Journal 45 (1), 33-42.

Bowen, M., L. Ducharme, and D. Shore. (1995). Stakeholders' Implicit Claims and Accounting Method Choice. Journal of Accounting and Economics 20 (3), 255-295.

Byun. S. (2014). The Effects of Abnormal Executive Pay Dispersion: Evidence from Firm Performance and Executive Turnover. Asia-Pacific Journal of Financial Studies 43, 621-648.

Cohen, D., A. Dey, and T. Lys. (2008). Real and Accrual-Based Earnings Management in the Pre- and Post-Sarbanes-Oxley Periods. The Accounting Review 83 (3), 757-787.

Cohen, D., and P. Zarowin. (2010). Accrual-based and Real Earnings Management Activities Around Seasoned Equity Offerings. Journal of Accounting and Economics 50, 2-19.

Core, J., R. Holthausen, and D. Larcker. (1999). Corporate Governance, Chief Executive Officer Compensation, and Firm Performance. Journal of Financial Economics 51, 371-406.

Cowherd, D. and D. Levine. (1992). Product Quality and Pay Equity Between Lower-Level Employees and Top Management: An Investigation of Distributive Justice Theory. Administrative Science Quarterly 37 (2), 302-320.

Dechow, P., R. Sloan, and A. Sweeney. (1995). Detecting Earnings Management. The Accounting Review 70 (2), $193-225$.

Dechow, p., and I. Dichev. (2002). The Quality of accruals and earnings: the role of accrual estimation errors. The Accounting Review 77 (Supplement), 35-59.

Deutsch, M. (1985). Distributive Justice: A Social Psychological Perspective. New Haven, CT: Yale University Press.

Francis, J., R. LaFond, R. Olsson, and K. Schipper. (2005). The Market Pricing of Accruals Quality. Journal of Accounting and Economics 39, 295-327.

Finkelstein, S. (1992). Power in Top Management Teams: Dimensions, Measurement, and Validation. The Academy of Management Journal 35 (3), 505-538.

Gunny, K. (2010). The Relation Between Earnings Management Using Real Activities Manipulation and Future Performance: Evidence from Meeting Earnings Benchmarks. Contemporary Accounting Research 27 (3), 855-888.

Hamm, S., Jung, M., and Wang, C. (2011). One Dollar CEO Salaries: An Empirical Examination of the Determinants and Consequences. Working paper.

Healy, P. (1985). The Effect of Bonus Schemes on Accounting Decisions. Journal of Accounting and Economics 7, 85-107.

Hribar, P., and D. Collins. (2002). Errors in Estimating Accruals: Implications for Empirical Research. Journal of Accounting Research 40 (1), 105-134.

Kahneman, D., and A. Tversky. (1979). Prospect Theory: An Analysis of Decision under Risk. Econometrica 47 (2), $263-292$.

Kothari, S.P., A. Leone, and C. Wasley. (2005). Performance Matched Discretionary Accrual Measures. Journal of Accounting and Economics 39, 163-197.

Lazear, E., and S. Rosen. (1981). Rank-Order Tournaments as Optimum Labor Contracts. The Journal of Political Economy 89 (5), 841-864.

Lee, K., B. Lev, and G. Yeo. (2008). Executive Pay Dispersion, Corporate Governance, and Firm Performance. Review of Quantitative Finance and Accounting 30, 315-338.

Leone, A., and S. Rock. (2001). Empirical Tests of Budget Ratcheting and Its Effect on Managers' Discretionary Accrual Choices. Journal of Accounting and Economics 33, 43-67.

Levine, D. (1991). Cohesiveness, Productivity, and Wage Dispersion. Journal of Economic Behavior and Organization 15, 237255. 
Main, B., C. O'Reilly, and J. Wade. (1993). Top executive pay: Tournament or teamwork?. Journal of Labor Economics 11, 606628.

Matsunaga, S., and C. W. Park. (2001). The Effect of Missing a Quarterly Earnings Benchmark on the CEO's Annual Bonus. The Accounting Review 76 (3), 313-332.

Mergenthaler, R., S. Rajgopal, and S. Srinivasan. (2011). CEO and CFO Career Penalties to Missing Quarterly Analysts Forecasts. Working paper.

Messersmith, J., J. Guthrie, Y. Ji, and J. Lee. (2011). Executive Turnover: The Influence of Dispersion and Other Pay System Characteristics. Journal of Applied Psychology 96 (3), 457-469.

Milbourn, T. (2003). CEO Reputation and Stock-based Compensation. Journal of Financial Economics 68, $233-262$.

Milgrom, P., and J. Roberts. (1988). An Economic Approach to Influence Activities in Organizations. American Journal of Sociology 94, S154-S178.

Pfeffer, J., and A. Davis-Blake. (1992). Salary Dispersion, Location in the Salary Distribution, and Turnover among College Administrators. Industrial and Labor Relations Review 45 (4), 753-763.

Pfeffer, J., and N. Langton. (1993). The Effect of Wage Dispersion on Satisfaction, Productivity, and Working Collaboratively: Evidence from College and University Faculty. Administrative Science Quarterly 38 (3), 382-407.

Rajgopal, S., and S. Srinivasan. (2006). Pay Dispersion in the Executive Suite. Working paper.

Roychowdhury, S. (2006). Earnings Management through Real Activities Manipulation. Journal of Accounting and Economics 42, 335-370.

Trueman, B., and S. Titman. (1988). An Explanation of Accounting Income Smoothing. Journal of Accounting Research 26, S127-S139. 


\section{NOTES}

